The authors describe three initiatives designed to increase the academic achievement and retention of historically underrepresented students (including females and underrepresented students of color) in engineering.

\title{
Diversity and Retention in Engineering
}

\author{
Cinda-Sue G. Davis, Cynthia J. Finelli
}

The engineer of the twenty-first century will compete in an increasingly global environment and face an expanding array of problems in the business sector as well as the social sector. To meet these challenges, the U.S. engineering education enterprise must produce graduates who are not only technically proficient but also diverse in terms of background, culture, outlook, and approach. Several national committees and reports have emphasized the critical importance of a diverse student and workforce population in the science, technology, engineering, and mathematics (STEM) fields (BEST, 2004a; 2004b; Chubin, May, and Babco, 2005; National Academy of Engineering, 2006; Wulf, 1998). Yet groups that have historically been underrepresented, particularly females and underrepresented students of color, are still not pursuing engineering degrees in proportion to their representation in the general public, despite decades of programs and interventions. Recent efforts at the University of Michigan (U-M), combining both curricular and cocurricular initiatives, offer some promising outcomes in terms of student academic achievement and retention. Three such initiatives are outlined in this chapter: (1) providing an opportunity for undergraduates to participate in research, (2) including service-learning in the first-year curriculum, and (3) introducing real-world context in a first-year computing course.

\section{Undergraduate Research}

Initially designed in 1989 as a retention program for historically underrepresented students, the Undergraduate Research Opportunity Program (UROP) was soon expanded to include all interested students in 1992.

\section{ॠWILEY}

\section{InterScience}


Today approximately twelve hundred first- and second-year students participate annually in research projects for work-study financial aid or academic credit with U-M faculty. Through the program, UROP students meet regularly with peer advisors who are upper-division UROP alumni, and UROP students are intentionally integrated into the university's core academic mission. Projects in which UROP students participate range from Physics of Spacecraft Propulsion: Analytical Modeling and Computer Simulation to Reception and Interpretation of the Films of Akira Kurosawa. Students participate in all aspects of the research enterprise, including literature searches, laboratory experimentation, and research presentations. Although UROP serves students in all of U-M's undergraduate schools and colleges, demand for positions is always great among engineering students.

Several assessment and evaluation efforts suggest that UROP participation positively influences academic achievement and retention, the extent of student participation in the educational experience, and participation in postgraduate activities related to academics. However, the findings vary by race or ethnicity, gender, and other student characteristics (Gregerman, 1999; Hathaway, Nagda, and Gregerman, 2002; Nagda and others, 1998).

One study involved a longitudinal retention analysis of 1,280 students, with UROP students carefully matched to non-UROP students who had applied to the program but who had not been accepted (Nagda and others, 1998). Overall, there was a positive (but nonsignificant) effect of UROP participation on retention. This effect was strongest for African American students: in that population, retention for UROP students was 90 percent, versus 82 percent for the control group. UROP participation also has a slight differential effect on retention rates for low-achieving students (88 percent versus 86 percent). Again, this effect was strongest for African American students (85 percent versus 73 percent).

Focus group data and an alumni survey were analyzed in a separate study to identify further benefits of the program (Hathaway, Nagda, and Gregerman, 2002). The focus group data indicated that UROP students tend to be more proactive than non-UROP students. They are more likely than non-UROP students to initiate activity with people, to anticipate problems before they arise, to act before being acted on, and to seek out help from individuals. In addition, UROP students are more likely to discuss how they interact with the academic environment and are more likely to see faculty, staff, and others as positive influences on their academic experiences. The alumni study (in which 291 UROP and non-UROP graduates responded to a survey about postgraduate educational pursuit and activities) found that students who participate in undergraduate research (UROP or other research) are significantly more likely to pursue postgraduate education (medical, law, or doctoral degrees) than control students. However, no differences by race or ethnicity in postgraduate educational pursuit were observed. 
Although the research findings cited previously are for all university UROP participants (including engineering students), the UROP program also undertook an engineering study in which retention for 5,228 undergraduate students who majored in engineering between 1998 and 2002 was compared for 857 UROP students and for 4,371 non-UROP students (Hathaway, 2003). Although retention for UROP and non-UROP students was not significantly different overall (83 percent and 81 percent retention for UROP and non-UROP, respectively), disaggregation of the data by race and gender yielded interesting results. For underrepresented students of color, retention is significantly higher for UROP than non-UROP students (77 percent versus 65 percent). This is also true for Asian and Asian American students (91 percent versus 87 percent), but there is no significant effect of UROP participation for white students. Similarly, three-way ANOVA comparison of UROP participation, ethnicity, and gender is also significant $(p<.001)$, indicating a different impact of UROP by gender and ethnicity (see Table 8.1). In particular, UROP has the greatest impact on retention for female underrepresented students of color (81 percent versus 60 percent), followed by Asian and Asian American males (94 percent versus 86 percent) and male underrepresented students of color (76 percent versus 68 percent).

\section{Service-Learning}

A second initiative at U-M involved introducing service-learning into the first-year curriculum. Since the mid-1900s, traditional undergraduate engineering education has focused on teaching specialized technical knowledge to students for the purpose of solving challenging problems. As a result, engineers of the last half-century have been highly technically trained but have often lacked professional skills, communication skills, and the broad education necessary to understand their impact in a global and social context (National Academy of Engineering, 2004). A service-learning course is

\section{Table 8.1. Retention Rates (in percent) by UROP Participation, Ethnicity, and Gender: A Three-Way ANOVA Comparison}

\begin{tabular}{|c|c|c|c|c|c|c|}
\hline \multirow[b]{2}{*}{ Group } & \multicolumn{3}{|c|}{ Males } & \multicolumn{3}{|c|}{ Females } \\
\hline & White & $\begin{array}{l}\text { Asian and } \\
\text { Asian } \\
\text { American }\end{array}$ & $\begin{array}{c}\text { Underrepresented } \\
\text { Students } \\
\text { of Color }\end{array}$ & White & $\begin{array}{l}\text { Asian and } \\
\text { Asian } \\
\text { American }\end{array}$ & $\begin{array}{c}\text { Underrepresented } \\
\text { Students } \\
\text { of Color }\end{array}$ \\
\hline UROP & 87 & 94 & 76 & 74 & 87 & 81 \\
\hline Non-UROP & 84 & 86 & 66 & 77 & 88 & 60 \\
\hline
\end{tabular}

Source: Data from Hathaway, 2003; used with permission. 
one way to address these curricular deficiencies and enhance social awareness in the engineering field (Coyle, Jamieson, and Oakes, 2006). Such a course includes three primary components: relevant and meaningful service in the community, enhanced academic learning, and purposeful civic learning (Howard, 2001).

There are many benefits to including a service-learning design project in the first-year engineering curriculum. First, it facilitates the development of professional skills in engineering students as they work in the community. Second, it brings active and reflective learning to students and has been shown to produce deeper understanding and better application of subject matter, increased ability to solve complex problems, and greater use of subject matter knowledge in analyzing a problem (Gallini and Moely, 2003; Tsang, 2000). Third, since historically underrepresented groups, including females and underrepresented students of color, often cite the ability to solve social problems as a prime reason for choosing a career in science or engineering (Astin and Sax, 1996; Seymour and Hewitt, 1997), servicelearning allows these students the opportunity to apply their skills in a social setting. By revealing the human aspect of engineering and making it socially relevant from the outset of their education, service-learning has the potential to increase diversity within the profession.

In fall 2004, 114 first-year students elected a service-learning section of Engineering 100, an introductory engineering class (Meadows and Jarema, 2006). Teams of students participated in a design project to develop innovative, low-cost greenhouses for several local, underfunded public schools. The greenhouses served the needs of the community, provided yearlong growing potential to supplement standard food offerings in schools and community service facilities, and supported early plantings for local community gardens. Interestingly, approximately 35 percent of the students who enrolled in this service-learning section were females and 15 percent were underrepresented students of color, while averages for the incoming class were about 25 percent and 10 percent, respectively.

To assess the effectiveness of the course in enhancing students' social awareness and improving the relevance of the curriculum, student evaluations of the course were collected at the end of the term. In Table 8.2, data from three terms when the course was taught without a service-learning component (fall 2002, fall 2003, and winter 2004) are compared to the term when service-learning was introduced (fall 2004). The same instructor taught the course all four terms.

Student evaluations of the service-learning term were significantly higher $(p<.001)$ than those during previous terms, indicating that servicelearning resulted in a greater sense of satisfaction with the course and the instructor. These data also indicate that the course succeeded in enhancing students' social awareness and in making the curriculum more relevant by getting students to grapple with social and economic issues that can arise in real-life engineering. 


\section{Table 8.2. Median Values for Student Responses to Items Pertinent to the Service-Learning Curriculum}

\begin{tabular}{|c|c|c|c|c|}
\hline & \multicolumn{2}{|c|}{$\begin{array}{l}\text { No Service-Learning } \\
\text { Component }\end{array}$} & \multicolumn{2}{|c|}{$\begin{array}{l}\text { Incorporating } \\
\text { Service-Learning }\end{array}$} \\
\hline & $\begin{array}{c}\text { Fall } 2002 \\
(n=70)\end{array}$ & $\begin{array}{l}\text { Fall } 2003 \\
\quad(n=75)\end{array}$ & $\begin{array}{l}\text { Winter } 2004 \\
\quad(n=94)\end{array}$ & $\begin{array}{l}\text { Fall 2004 } \\
(n=114)\end{array}$ \\
\hline $\begin{array}{l}\text { Overall, this was an excellent } \\
\text { course. }\end{array}$ & 3.7 & 3.7 & 3.8 & 4.6 \\
\hline $\begin{array}{l}\text { Overall, the instructor was an } \\
\text { excellent teacher. }\end{array}$ & 4.1 & 3.9 & 4.0 & 4.7 \\
\hline $\begin{array}{l}\text { I learned a great deal from this } \\
\text { course. }\end{array}$ & 3.7 & 3.9 & 3.7 & 4.4 \\
\hline $\begin{array}{l}\text { I had a strong desire to take } \\
\text { this course. }\end{array}$ & 3.0 & 3.1 & 3.1 & 4.0 \\
\hline $\begin{array}{l}\text { This course helped me understand } \\
\text { the rewards and challenges of } \\
\text { being an engineer. }\end{array}$ & 3.9 & 3.9 & 3.9 & 4.5 \\
\hline $\begin{array}{l}\text { This course helped me understand } \\
\text { the range of skills/disciplines } \\
\text { needed in engineering. }\end{array}$ & 3.9 & 3.9 & 3.9 & 4.4 \\
\hline $\begin{array}{l}\text { This course helped me understand } \\
\text { social and economic considera- } \\
\text { tions in engineering. }\end{array}$ & 4.1 & 4.0 & 3.9 & 4.4 \\
\hline $\begin{array}{l}\text { I have a sense of pride and } \\
\text { accomplishment as a result of } \\
\text { completing my projects. }\end{array}$ & 3.9 & 3.9 & 3.9 & 4.6 \\
\hline $\begin{array}{l}\text { I have become more aware of the } \\
\text { responsibilities engineers have } \\
\text { as professionals. }\end{array}$ & 4.0 & 4.1 & 4.0 & 4.6 \\
\hline $\begin{array}{l}\text { I will think more carefully about } \\
\text { engineering's impact on society } \\
\text { because of this course. }\end{array}$ & 3.8 & 3.8 & 3.8 & 4.5 \\
\hline
\end{tabular}

Notes: Student responses were on a 5 -point Likert scale from $1=$ strongly disagree to $5=$ strongly agree. The same instructor taught the course during all four terms.

Source: Meadows and Jarema, 2006; reprinted with permission.

\section{Real-World Context}

Another initiative intended to increase the academic achievement of historically underrepresented students was to introduce real-world context in the first-year computing course (Engineering 101). In particular, to decrease the achievement gap between underrepresented students of color and others (white students and Asian and Asian American students) and between females and males, a two-phase analysis was conducted. First, to identify factors that help or hinder all students in the course, survey data were collected during the first and eighth weeks of the fall 2003 term in 
one Engineering 101 course. Of the 185 enrolled students, 64 percent (119) completed both surveys. Data suggested that many students did not perceive computer programming and algorithmic thinking as useful and important to their future as engineers and that this perception had a negative effect on their motivation to engage with the course material. This finding was especially a matter for concern because usefulness and importance are two dimensions of student motivation that have been shown to affect persistence and achievement (Pintrich and Zusho, 2002; Wigfield and Eccles, 2000).

The second phase of the initiative involved modifying Engineering 101 to change students' perception about the importance and usefulness of programming, thereby motivating students to engage with the course (Burn and Holloway, 2006). In fall 2004, the instructor modified the course by consistently emphasizing and demonstrating to students the role of algorithmic thinking and programming in the work of engineers. As much as possible, the weekly programming assignments were also placed within the context of current events, real-world technologies, or applications to improve society. Each week a significant amount of lecture time (occasionally a full day) was devoted to introducing the assignment, the ideas behind it, and its realworld context.

To evaluate the effect of deliberately emphasizing the importance of programming, students in both the modified course and a separate section serving as a quasi-control group completed surveys during the second and thirteenth weeks. The response rate for students completing both surveys was 43 percent in both the modified course and the control section (96 of 221 students in the modified course and 98 of 226 students in the control section). From the beginning of the course to the thirteenth week, responses to the statement "It is important that engineering majors learn to program ( 1 = strongly disagree . . 4 = strongly agree $)$ " diverged for the two groups. The control group's perception of the importance of learning to program decreased markedly $(-0.42)$ from the second to the thirteenth week of the term, while the decrease was negligible $(-0.18)$ in the modified course. This difference between the sections was statistically significant. Hence exposure to the intricacies of algorithmic thinking did not detract from students' sense of its relevance in the modified section as it did in the control group.

It was difficult to evaluate the effect of adding real-world context to weekly assignments because it was not possible to adjust for the different assignments in the control group. However, a comparison of student survey responses from the fall 2003 course (in which traditional assignments were used) and the modified fall 2004 course (in which real-world context was introduced) provides an interesting insight. Both courses were taught by the same instructor. In both sections, students were asked to respond to the statement "I can see/imagine how the ideas from this class will be 
applied in my future ( $1=$ strongly disagree, $\ldots .5=$ strongly agree $)$ " at the second and thirteenth weeks. In the traditionally taught course, there was a statistically significant decrease $(-0.50)$ in students' perceptions of how course ideas would apply in the future from the second to the thirteenth weeks, while in the modified course there was no statistically significant difference. This result suggests the intervention had a positive effect.

A comparison of class grades between the students in the fall 2003 and fall 2004 courses is also illuminating. The grade gap between female and male students of all races dropped from 0.42 in fall 2003 to 0.17 in fall 2004, while the gap between underrepresented students of color and other students dropped from 0.68 to 0.56 . This change could be traced to both improved exam performance and improved homework performance; the difference was best explained by improved exam performance for females and by improved homework performance for underrepresented students of color.

\section{Discussion}

The National Academy of Engineering publication Educating the Engineer of 2020 (2005) eloquently described how the undergraduate engineering (and science and mathematics) learning environment is changing in this century. Among other things, engineering undergraduate education must deal with changing "student demographics, with greater diversity from the perspective of academic preparation, career aspirations, and ethnic background that require approaches to learning, teaching, and research designed intentionally to respect (and celebrate) this diversity" (p. 36). As Linda Katehi, former dean of the College of Engineering at Purdue, wrote, "The new engineering curriculum must take into account that in the future students will learn in a completely different way. Up to now, engineering schools have developed curricula by creating scenarios or predicting the problems we expect to face. In doing so, we have focused on knowledge rather than skills. ... Engineers whose education is built from the bottom up cannot comprehend and address big problems. They get lost in irrelevant details" (pp. 153-154).

What is particularly exciting about the initiatives discussed in this chapter is how they are changing the way undergraduate engineering education is approached. Innovations designed to help female students and underrepresented students of color actually benefited all students and aligned the engineering undergraduate experience much more closely to the ideals described in Educating the Engineer of 2020. Social relevance, respecting diversity, and problem solving, in addition to knowledge, seeing the big picture, and identification with the profession, are all components vital to the education and future careers of engineers in this century. And all are important components of the efforts described in this chapter. Introducing undergraduate research experiences, service-learning opportunities, and 
social and professional relevance to the engineering curriculum can strengthen the education and success of all students.

\section{References}

Astin, H. S., and Sax, L. J. "Developing Scientific Talent in Undergraduate Women." In Davis, C. S., and others (eds.), The Equity Equation: Fostering the Advancement of Women in the Sciences, Mathematics, and Engineering. San Francisco: Jossey-Bass, 1996.

BEST: Building Engineering and Science Talent. A Bridge for All: Higher Education Design Principles to Broaden Participation in Science, Technology, Engineering, and Mathematics. San Diego, Calif.: BEST, 2004a.

BEST: Building Engineering and Science Talent. The Talent Imperative: Diversifying America's Science and Engineering Workforce. San Diego, Calif.: BEST, 2004b.

Burn, H., and Holloway, J. "Why Should I Care? Student Motivation in an Introductory Programming Course." Proceedings of the ASEE Annual Conference and Exposition, Chicago, 2006. (CD-ROM)

Chubin, D. E., May, G. S., and Babco, E. L. "Diversifying the Engineering Workforce." Journal of Engineering Education, 2005, 94(1), 73-86.

Coyle, E. J., Jamieson, L. H., and Oakes, W. C. "Integrating Engineering Education and Community Service: Themes for the Future of Engineering Education." Journal of Engineering Education, 2006, 95(1), 7-11.

Gallini, S. M., \& Moely, B. E. "Service-Learning and Engagement, Academic Challenge, and Retention." Michigan Journal of Community Service Learning, 2003, 10(1), 5-14.

Gregerman, S. R. "Improving the Academic Success of Diverse Students Through Undergraduate Research." Council on Undergraduate Research Quarterly, 1999, 20(2), 54-59.

Hathaway, R. S. "UROP Engineering Retention Analyses: UROP and Non-UROP Engineering Retention Comparison." Unpublished report, University of Michigan, 2003.

Hathaway, R. S., Nagda, B. A., and Gregerman, S. R. "The Relationship of Undergraduate Research Participation to Graduate and Professional Educational Pursuit: An Empirical Study." Journal of College Student Development, 2002, 43(5), 614-631.

Howard, J. Service Learning Course Design Workbook: Companion Volume to Michigan Journal of Community Service Learning. Ann Arbor: OCSL Press, University of Michigan, 2001.

Meadows, L., and Jarema, S. "An Evaluation of the Impact of a Service-Learning Project in a Required First-Year Engineering Course." Proceedings of the ASEE Annual Conference and Exposition, Chicago, 2006. (CD-ROM)

Nagda, B. A., and others. "Undergraduate Student-Faculty Research Partnerships Affect Student Retention." Review of Higher Education, 1998, 22(1), 55-72.

National Academy of Engineering. The Engineer of 2020: Visions of Engineering in the New Century. Washington, D.C.: National Academies Press, 2004.

National Academy of Engineering. Educating the Engineer of 2020: Adapting Engineering Education to the New Century. Washington, D.C.: National Academies Press, 2005.

National Academy of Engineering. Rising Above the Gathering Storm: Energizing and Employing America for a Brighter Economic Future. Washington, D.C.: National Academies Press, 2006.

Pintrich, P., and Zusho, A. "Student Motivation and Self-Regulated Learning in the College Classroom." In J. C. Smart and W. G. Tierney (eds.), Higher Education: Handbook of Theory and Research. Boston: Kluwer, 2002.

Seymour, E., and Hewitt, N. Talking About Leaving: Why Undergraduates Leave the Sciences. Boulder, Colo.: Westview Press, 1997.

Tsang, E. (ed.). Projects That Matter: Concepts and Models for Service Learning in Engineering, Vol. 14. Washington, D.C.: American Association for Higher Education, 2000. 
Wigfield, A., and Eccles, J. S. "Expectancy-Value Theory of Motivation." Contemporary Educational Psychology, 2000, 25(1), 68-81.

Wulf, W. A. "The Urgency of Engineering Education Reform." Bridge, 1998, 28(1), 1-7.

CINDA-SUE G. DAVIS is director of the Women in Science and Engineering Program at the University of Michigan.

CYNTHIA J. FINELLI is managing director of the Center for Research on Learning and Teaching (CRLT) North, a joint venture between the University of Michigan College of Engineering and CRLT. She is also an associate research scientist of engineering education. 